\title{
OPTIMALISASI APLIKASI WHATSAPP DAN GOOGLE MEET UNTUK PENYAMPAIAN MATERI PADA PEMBELAJARAN JARAK JAUH
}

\section{Dwi Ratih Yuliawati}

SMA N 1 Rembang, Jawa Tengah

Email: kayismanis@gmail.com

\section{Info Artikel}

Sejarah Artikel:

Diserahkan 29 April 2021

Direvisi 06 Mei 2021

Disetujui 10 Mei 2021

\section{Keywords:}

Whatapps, Google Meet, Distance Learning

\section{Abstract}

This study aims to analyze the use of the Whatsapp and Google Meet applications as an effort to optimize the delivery of material in distance learning at SMA N 1 Rembang. The research method used by researchers is descriptive qualitative research. Data collection techniques using interview techniques, observation, and documentation. The data obtained are in the form of interviews, observations and school documentation. Data analysis techniques using data verification techniques, data reduction and conclusions. To check the degree of truth using source triangulation.

Teacher creativity is required to make students comfortable and enjoy the learning process without having to leave home and still follow the learning process. By combining several applications will complement each other so that it becomes the perfect learning. The use of the WhatsApp and Google Meet applications in one lesson will be complete in the distance learning process. Teachers can communicate easily using WhatsApp, can explain material clearly and can monitor students with Google Meet. In addition, teachers can provide attitude assessments automatically. The process of supervision in online learning using Whatsapp and Google Meet can also be done easily.

\section{Abstrak}

Penelitian ini bertujuan untuk menganalisis penggunaan aplikasi Whatsapp dan Google Meet sebagai upaya optimalisasi penyampaian materi dalam pembelajaran jarak jauh di SMA N 1 Rembang.

Metode penelitian yang dipakai oleh peneliti adalah penelitian deskriptif kualitatif. Teknik pengumpulan data menggunakan teknik wawancara, observasi, dan dokumentasi. Data yang diperoleh berupa hasil wawancara, hasil observasi dan dokumentasi sekolah. Teknik analisis data menggunakan teknik verivikasi data reduksi data dan kesimpulan. Untuk mengecek derajat kebenarannya menggunakan trianggulasi sumber.

Kreatifitas guru dituntut untuk membuat siswa nyaman dan menikmati proses pembelajaran tanpa harus meninggalkan rumah dan tetap mengikuti proses pembelajaran. Dengan penggabungan beberapa aplikasi akan saling melengkapi sehingga menjadi pembelajaran yang sempurna. Penggunaan aplikasi WhatsApp dan Google Meet dalam satu pembelajaran akan menjadi lengkap dalam proses pembelajaran jarak jauh. Guru dapat berkomunikasi dengan mudah menggunakan WhatsApp, dapat menjelaskan materi dengan jelas dan dapat memantau siswa dengan Google Meet. Selain itu guru dapat memberikan penilaian sikap secara otomatis. Proses supervise dalam pembelajaran ksecara daring dengan menggunakan Whatsapp dan Google Meet juga dapat dilakukan dengan mudah. 


\section{Dwi Ratih Yuliawati \\ OPTIMALISASI APLIKASI WHATSAPP DAN GOOGLE MEET UNTUK PENYAMPAIAN .... WASIS: Jurnal Ilmiah Pendidikan. Volume 2, Nomor 1, Mei 2021, hlm. 62-67}

\section{PENDAHULUAN}

Corona Virus Disease (Covid-19) dinyatakan sebagai pandemi pada 11 Maret 2020, suatu penyakit yang mewabah pada hampir seluruh negara di dunia. Wabah Covid-19 menjadikan semua orang merasa khawatir dan cemas, karena penyebaran Covid-19 sangat begitu cepat dan hampir diseluruh negara di dunia terkena Covid-19. Indonesia pun masuk dalam keadaan darurat Covid-19, bahkan di sebagian wilayah Indonesia masuk pada kategori zona merah. Kebijakan baru terjadi pada dunia pendidikan merubah pembelajaran yang biasanya dilakukan secara langsung di sekolah secara tatap muka menjadi belajar dari rumah. Pemerintah menganjurkan untuk stay at home dan physical and social distancing harus diikuti perubahan belajar tatap muka menjadi Pembelajaran Jarak Jauh.

Berdasarkan Surat Edaran Kemendikbud yang dilanjutkan dengan Surat Edaran dari Disdik Jawa Tengah mulai tanggal 16 Maret 2020 siswa diminta untuk belajar di rumah. Pembelajaran dilaksanakan dengan cara online atau daring. Kebijaksanaan ini dikeluarkan dalam rangka untuk membatasai penularan virus Covid-19. Perubahan ini juga dirasakan oleh guru. Guru diminta bekerja dari rumah. Guru harus dapat memandu pembelajaran secara daring dari rumah. Guru juga harus membuat jurnal pembelajaran daring dari rumah. Selama ini guru melakukan seluruh kegiatan pembelajaran dari rumah.

Banyak teknik yang dapat digunakan dengan pembelajaran jarak jauh. Mulai dari yang simple ke teknik yang kompleks. Pembelajaran online pada kondisi darurat yang efektif perlu mempertimbangkan berbagai faktor (Handayani, 2020). Pemilihan teknik ini harus disesuaikan dengan sarana dan prasarana yang ada. Baik yang dimiliki guru maupun siswa. Kompetensi guru dan siswa juga mempengaruhi pemilihan teknik yang akan digunakan. Jika sarana terpenuhi tetapi guru atau siswa tidak memiliki kompetensi terhadap hal tersebut, maka teknik yang dipilih tidak bisa dilaksanakan. Begitu juga sebaliknya jika penguasaan kompetensi terhadap sebuah teknik ada, tetapi sarana tidak mendukung maka mustahil untuk melaksanakan teknik yang dipilih.

Saat ini hampir semua kalangan masyarakat menggunakan smart phone yang berbasis android. Rata-rata dari masyarakat memilih menggunakan aplikasi Whatsapp untuk menjalin komunikasi dengan orang lain. Pemilihan Whatsapp sebagai sarana berkomunikasi didasarkan pada murahnya biaya quota yang dikeluarkan dengan fasilitas dan kemudahan yang diberikan pada layangan tersebut. Pada aplikasi Whatsapp tersedia layanan pembuatan grup yang dapat diisi lebih dari 100 orang anggota dalam satu grup. Dengan demikian kita bisa memanfaatkan membuat grup kelas melalui Whatsapp yang berisi sejumlah siswa sesuai yang kita kehendaki.

WhatsApp memiliki berbagai fungsi, di antaranya adalah bisa mengirim pesan, chat grup, berbagi foto, video, dan dokumen. Namun, penggunaan media sosial tersebut tidak terlalu dimanfaatkan sebagai media literasi oleh siswa (Sahidillah \& Miftahurrisqi, 2019). Siswa hanya meluangkan waktu dengan Whatsapp sebagai media sosial sebatas berkirim pesan, foto maupun dokumen yang tidak memuat literasi sama sekali. Akibatnya, siswa cenderung apatis terhadap keberadaan WhatsApp sebagai media sosial yang bisa digunakan untuk media literasi.

Teknik pembelajaran menggunakan media sosial Whatsapp ini paling sederhana. Saat ini smart phone bukan barang sekuder lagi, melainkan primer. Sehingga hampir semua siswa menggunakan smart phone berbasis android. Daya dukung inilah yang bisa kita manfaatkan untuk pembelajaran berbasis daring. Kemudahan yang didapatkan dalam menggunakan aplikasi Whatsapp dalam pembelajaran yaitu siswa dan guru tidak perlu mengikuti pelatihan terlebih dahulu. Rata-rata dari siswa dan guru sudah menguasai penggunaan Whatsapp.

Penggunaan suatu teknik dalam pembelajaran pasti ada kelemahan dan kelebihan. Kelebihan penggunaan Whatsapp diantaranya low cost karena tidak menghabiskan banyak paket data interet dan tidak memberatkan system android saat bekerja sehingga stabilitas signal selama dalam jaringan android masih bisa menjangkau pembelajran akan berjalan lancar. Namun kelemahan penggunaan teknik ini, pembelajaran bersama tidak dapat dilakukan dengan video conference. Hal ini karena video conference dalam Whatsapp hanya dibatasi maksimal 8 orang saja. Untuk itu perlu dipadukan dengan teknik lain yang bisa melakukan video conference dengan semua siswa.

Ada banyak teknik lain dari aplikasi yang menawarkan fasilitas video conference dengan anggota lebih dari 100 orang. Salah satunya adalah layanan yang disediakan oleh Google yaitu Google Meet. Teknik ini menawarkan fasilitas video conference yang dapat digunakan sebagai sarana yang dimiliki guru dan siswa menunjang proses pembelajaran. Google Meet merupakan bagian fitur dari Google Hangout 


\section{Dwi Ratih Yuliawati \\ OPTIMALISASI APLIKASI WHATSAPP DAN GOOGLE MEET UNTUK PENYAMPAIAN .... WASIS: Jurnal Ilmiah Pendidikan. Volume 2, Nomor 1, Mei 2021, hlm. 62-67}

yang bisa memberikan fasilitas video conference hingga 250 peserta secara live. Walaupun berbayar, Google Meet merupakan satu dari beberapa fitur yang tersedia di Google Suite (layanan berbayar Google). Harga langganannya lebih murah dibandingkan dengan aplikasi khusus video conference lainnya. Aplikasi tersebut mudah dan praktis. Asalkan mempunyai akun Google maka siswa dapat mengikuti pembelajaran daring dengan lancar.

Penggunaan aplikasi Whatsapp dengan Google Meet dalam kegiatan pembelajaran dapat membantu guru dalam penyampaian materi pembelajaran secara maksimal. Penelitian yang dilakukan oleh Suryadi, dkk (2018) menjelaskan bahwa WhatsApp mempengaruhi disiplin belajar siswa, sehingga aktivitas belajar siswa menurun dan lemah dalam mengikuti pembelajaran. Penelitian di atas dilakukan saat pembelajaran di dalam kelas. Apabila dilakukan dengan metode yang lebih menarik, siswa juga bisa lebih tertarik dalam belajar dan media sosial digunakan sebagai sarana untuk pembelajaran, justru bisa meningkatkan disiplin belajar siswa. Sependapat dengan penelitian dari Alqahtani, dkk (2018) menunjukkan bahwa penggunaan media sosial, seperti WhatsApp dapat memungkinkan siswa untuk memahami dan terlibat dalam menggunakannya sebagai bagian dari pembelajaran. Penelitian yang dilakukan Sahidillah dan Miftahurrisqi (2019) memberikan kesimpulan bahwa penggunaan Whatsapp sebagai media literasi digital siswa dapat berbagi materi pelajaran,fitur forward memudahkan untuk mengirim atau melanjutkan ke teman yang lain, tanpa harus membuka pada manajer file di gawai.

Guru sebagai fasilitator dapat menyajikan presentasi bahan ajar yang berupa powerpoint (ppt) pada vicon dengan Google Meet ini. Begitu juga dengan siswa yang ingin mempresentasikan hasil diskusi mereka. Kolaborasi dari kedua aplikasi tersebut dalam pembelajaran jarak jauh diharapkan dapat membantu tercapainya tujuan pembelajaran.

Penelitian ini bertujuan untuk menganalisis penggunaan aplikasi Whatsapp dan Google Meet sebagai upaya optimalisasi penyampaian materi dalam pembelajaran jarak jauh di SMA N 1 Rembang.

\section{METODE PENELITIAN}

Metode penelitian yang dipakai oleh peneliti adalah penelitian deskriptif kualitatif. Penelitian ini dilakukan di SMA N 1 Rembang dengan memaparkan fenomena yang terjadi terkait dengan kegiatan pembelajaran yang berlangsung di sekolah.

Teknik pengumpulan data menggunakan teknik wawancara, observasi, dan dokumentasi. Data yang diperoleh berupa hasil wawancara, hasil observasi dan dokumentasi sekolah. Teknik analisis data menggunakan teknik verivikasi data reduksi data dan kesimpulan. Untuk mengecek derajat kebenarannya menggunakan trianggulasi sumber.

\section{HASIL DAN PEMBAHASAN}

\section{Proses Pembelajaran}

Pembelajaran sebelum adanya pandemi Covid-19 dilakukan dengan tatap muka secara langsung antara guru dan siswa. Pada pembelajaran tatap muka guru dapat berinteraksi langsung dengan siswa. Guru bisa menerangkan materi dengan sejelas mungkin menggunakan beberapa media sekaligus secara leluasa untuk menghasilkan pemahaman materi yang bagus dari dari siswa. Guru juga bisa mengetahui secara langsung respon dan semua hal yang dilakukan siswa pada saat guru menyampaikan materi. Guru bisa mengamati dengan detail pada saat siswa melakukan respon yang positif maupun negatif terhadap pembelajaran yang disampaikan oleh guru.

Pembelajaran tatap muka membuat guru mudah memahami tingkat pemahan siswa. Guru bisa dengan luwes memainkan ekspresi muka dan bahasa tubuh sehingga membuat siswa lebih paham akan apa yang dikehendaki guru. Guru dapat memeriksa penugasan berupa pemberian soal yang dikerjakan siswa saat itu juga. Dari penugasan tersebut guru bisa mengerti apakah seorang siswa sudah mempunyai pemahaman yang bagus terhadap materi yang diajarkan atau belum. Guru juga dapat meminta beberapa siswa untuk maju mengerjakan soal yang diberikan untuk kemudian membahasnya bersama siswa di kelas. Guru dapat menyimpulkan hasil pembelajaran pada saat itu di akhir pertemuan.

Hal tersebut tentunya akan sulit dilakukan pada pembelajaran jarak jauh. Namun, guru harus tetap melakukan proses pembelajaran dengan baik. Guru harus mampu menemukan cara yang sesuai dalam melakukan proses pembelajaran bersama siswa (Setyorini, 2020). Pada pembelajaran jarak jauh, guru memilih memanfaatkan aplikasi Whatsapp karena Whatsapp merupakan aplikasi termudah yang bisa dimanfaatkan oleh guru maupun siswa. Guru memberikan salam, menyapa siswa, dan mencatat daftar kehadiran siswa dengan mengetik chat. Guru bisa menerangkan materi 


\section{Dwi Ratih Yuliawati \\ OPTIMALISASI APLIKASI WHATSAPP DAN GOOGLE MEET UNTUK PENYAMPAIAN ... WASIS: Jurnal Ilmiah Pendidikan. Volume 2, Nomor 1, Mei 2021, hlm. 62-67}

dengan chat, voice note maupun melakukan perekaman video pada materi yang akan dijelaskan kepada siswa untuk selanjutnya dikirim ke kelas pada grup Whatsapp. Guru juga dapat memberikan berbagai macam penugasan melalui grup Whatsapp (Dewi, 2019).

Pembelajaran secara langsung berbeda dengan pembelajaran daring. Selama ini pembelajaran daring dilakukan dengan menggunakan aplikasi yang termudah, yaitu WhatsApp. Guru memberi penjelasan tentang materi melalui chat pada laptop atau handphone. Pada saat itu, guru tidak tahu, apakah siswa melihat chat guru atau ditinggal melakukan kegiatan yang lain. Kegiatan tersebut bisa berupa makan, minum, tidur, mengantar orang tuanya, mandi, dan lain-lain. Guru akan tahu, jika tibatiba siswa dipanggil namun tidak ada jawaban. Siswa tersebut tidak membalas chat guru untuk menjawab. Ini menunjukkan bahwa siswa tersebut keberadaannya dipertanyakan.

Jika guru memberi pertanyaan, semua siswa menjawab dengan chat-chat di WhatsApp. Ini membuat daya penyimpanan handphone menjadi penuh. Selain itu, jawaban siswa A akan dapat dilihat siswa yang lain. Dimungkinkan siswa yang berikutnya akan menjawab mencontoh siswa A dengan salin dan tempel.

Pembelajaran jarak jauh diharapkan tetap dapat menjaga siswa aktif dalam kegiatan pembeljaaran. Dalam pembelajaran jarak jauh menuntut siswa untuk dapat melakukan aktivitas belajar secara mandiri (Purbawati dkk, 2020). Guru menggunakan sistem pembelajaran jarak jauh dengan menggabungkan 2 aplikasi, yaitu WhatsApp dan Google Meet. Dengan Whatsapp guru akan memberi instruksi yang harus dilakukan siswa. Guru memulai kegiatan pendahuluan berupa salam, menanyakan kabar siswa, dan mengecek pemahaman siswa untuk materi sebelumnya ditulis dengan chat Whatsapp.

Pada kegiatan inti dapat dilakukan dengan daring yang interaktif dengan menggunakan aplikasi video conference (vicon). Vicon ini berarti guru dan siswa bertemu langsung namun tidak dalam satu ruangan. Guru di sekolah dan siswa di rumah. Berarti dalam jarak jauh. Hal itu dapat dilakukan dengan salah satu aplikasi yaitu Google Meet. Menurut Sawitri (2020) dengan Google Meet yang mudah dan praktis dapat dilakukan kegiatan inti dari mengamati sampai menyimpulkan yang merupakan tahap akhir dalam kegiatan inti. Pada waktu mengamati dapat dilakukan presentasi. Presentasi dapat berupa power point, word, excel, video, dan audio. Semuanya mudah dijalankan dengan Google Meet ini. Guru dapat memberi pertanyaan pada siswa setelah proses presentasi. Guru dapat meminta siswa untuk presentasi jawaban dari pertanyaan yang diajukan guru. Jawaban siswa dan penjelasannya dapat dilihat oleh teman yang lain. Dengan demikian siswa lain yang tidak sependapat, akan mengajukan jawaban lain. Pada saat ini guru dapat mengetahui semua keadaan siswa. Hal itu dilakukan dengan meminta semua siswa untuk mengaktifkan kamera. Jika ada siswa yang tidak menyimak atas jawaban temannya, guru dapat menegur siswa tersebut. Dokumentasi dari kegiatan pembelajaran jarak jauh menggunakan aplikasi Google Meet disajikan pada Gambar 1.

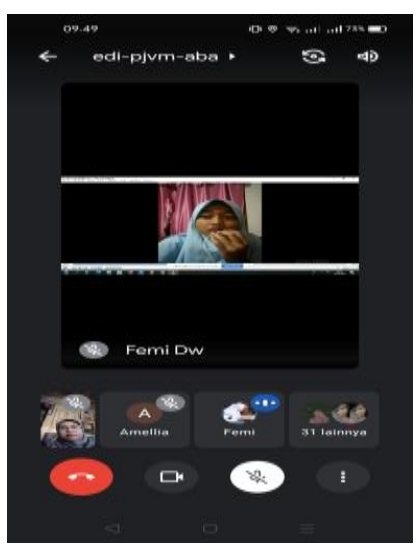

Gambar 1. Suasana Pembelajaran daring dengan Google Meet

Pada waktu guru menyampaikan apersepsi untuk memusatkan perhatian siswa yang berhubungan dengan materi yang akan disampaikan, guru dapat menayangkan video. Guru juga dapat memanfaatkan fitur paint pada komputer untuk membantu presentasi langsung seperti papan tulis. Fitur paint digunakan pada saat guru ingin menerangkan sambil menulis apa yang dimaksud sehingga siswa dapat melihat langsung dan membantu untuk memahami materi yang dijelaskan. Paint adalah fitur bawaan dari komputer. Fitur tersebut dapat dicari dengan cara klik start dan search.

Perpaduan antara WhatsApp dan Google Meet dalam proses pembelajaran kegiatan pendahuluan dimulai dengan WhatsApp. Pendahuluan berisi salam, mengecek daftar hadir, menanyakan kabar siswa, dan memotivasi. Untuk mengetahui apakah semua siswa online apa tidak maka guru meminta siswa untuk presensi di WhatsApp ini. Namun hal ini tidak efektif. Setiap siswa akan mengetik presensi dan 


\section{Dwi Ratih Yuliawati \\ OPTIMALISASI APLIKASI WHATSAPP DAN GOOGLE MEET UNTUK PENYAMPAIAN .... WASIS: Jurnal Ilmiah Pendidikan. Volume 2, Nomor 1, Mei 2021, hlm. 62-67}

guru kesulitan untuk mengecek. Maka untuk presensi ini sebaiknya siswa disarankan menggunakan Google Meet. Otomatis guru langsung bisa mengecek siswa yang tidak online yaitu siswa yang tidak masuk di Google Meet. Guru dapat melanjutkan dengan kegiatan inti yaitu menyampaikan materi untuk hari itu. Menurut Sriyatun (2021) penggunaan aplikasi Whatsapp dan Google Meet dalam pembelajaran dapat mendukung proses pembelajaran dengan baik. Kolaborasi dari 2 aplikasi tersebut membantu guru dalam menyampaikan pesan pembelajaran kepada siswa.

\section{Proses Supervisi Pembelajaran}

Pembelajaran jarak jauh tetap dilakukan supervisi. Supervisi dilaksanakan oleh kepala sekolah sesuai dengan tupoksi kepala sekolah. Berdasarkan hasil wawancara dengan kepala sekolah SMA N 1 Rembang terkait dengan proses supervisi pada pembelajaran jarak jauh, beliau mengungkapkan bahwa:

"Proses supervisi tidak menjadi masalah apalagi jika pembelajaran dilakukan dengan aplikasi WhatsApp. Saya dapat masuk di grup kelas sehingga dapat memantau kegiatan guru dalam pembelajaran jarak jauh."

Teknik pembelajaran jarak jauh juga dapat diamati secara langsung oleh kepala sekolah melalui grup Whatsapp. Kepala sekolah dapat mengetahui bagaimana teknik proses pembelajaran apakah dengan penugasan ataupun dengan teknik ceramah. Kepala sekolah juga menyampaikan bahwa:

\section{"Saya dapat mengetahui teknik pembelajaran yang dilakukan guru selama pembelajaran jarak jauh baik menggunakan aplikasi Whatsapp maupun aplikasi Google Meet. Saya juga mengikuti pembelajaran yang dilakukan guru menggunakan Google Meet."}

Kepala sekolah dapat mengetahui teknik atau aplikasi apa yang digunakan guru pada pembelajaran daring tersebut. Pembelajaran menyenangkan atau tidak juga bisa diketahui. Pembelajaran sekedar memberi tugas atau tidak juga kepala sekolah akan tahu. Hal yang sama juga bisa dilakukan pada Google Meet. Jadi jika kepala sekolah menjadi anggota grup kelas akan mengetahui semua pekerjaan guru di kelas tersebut. Tugas itu dilaksanakan tanpa harus menunggui seperti pembelajaran tatap muka. Tugas itu dapat dilaksanakan dengan melakukan pekerjaan yang lain. Kepala sekolah dapat membawahi banyak rombel untuk dilakukan supervise, hal ini dikarenakan proses tersebut dapat dilakukan secara online. Hal tersebut sesuai yang disampaikan oleh kepala sekolah sebbagai berikut.

"Proses suspervisi pada pembelajaran jarak jauh seperti ini apabila dengan banyak rombel dapat dilakukan dengan mudah. Hal tersebut dikarenakan semua prosesnya dapat dilakukan secara daring.,

Pelaksanaan supervisi bisa dilakukan dengan berbasis kelas atau berbasis guru. Jadi kepala sekolah bisa masuk grup berdasarkan guru yang akan disupervisi atau kelas.

\section{SIMPULAN}

Kondisi saat ini membawa banyak peluang bagi guru-guru dalam merancang dan menyelenggarakan kegiatan pembelajaran yang kreatif. Kreatifitas guru dituntut untuk membuat siswa nyaman dan menikmati proses pembelajaran tanpa harus meninggalkan rumah dan tetap mengikuti proses pembelajaran. Dengan penggabungan beberapa aplikasi akan saling melengkapi sehingga menjadi pembelajaran yang sempurna. Penggunaan aplikasi WhatsApp dan Google Meet dalam satu pembelajaran akan menjadi lengkap dalam proses pembelajaran jarak jauh. Guru dapat berkomunikasi dengan mudah menggunakan WhatsApp, dapat menjelaskan materi dengan jelas dan dapat memantau siswa dengan Google Meet. Selain itu guru dapat memberikan penilaian sikap secara otomatis. Proses supervise dalam pembelajaran ksecara daring dengan menggunakan Whatsapp dan Google Meet juga dapat dilakukan dengan mudah.

\section{DAFTAR PUSTAKA}

Alqahtani, M. S., Bhaskar, C. V., Vadakalur Elumalai, K., \& Abumelha, M. (2018). WhatsApp: An Online Platform for University-Level English Language Education. Arab World English Journal, 9(4), 108-121.

Dewi, S. R. (2019). Utilizing WhatsApp Application for Teaching Integrated English (A Case Study at University of Technology Yogyakarta). Refleksi Edukatika: Jurnal Ilmiah Kependidikan, 9(2). 
Dwi Ratih Yuliawati

OPTIMALISASI APLIKASI WHATSAPP DAN GOOGLE MEET UNTUK PENYAMPAIAN ....

WASIS: Jurnal Ilmiah Pendidikan. Volume 2, Nomor 1, Mei 2021, hlm. 62-67

Handayani, L. (2020). Keuntungan, Kendala dan Solusi Pembelajaran Online Selama Pandemi Covid-19: Studi Ekploratif di SMPN 3 Bae Kudus. Journal of Industrial Engineering \& Management Research, 1(2), $15-23$.

Purbawati, C., Rahmawati, L. E., Hidayah, L. N., \& Wardani, L. S. P. (2020). Tingkat Partisipasi Siswa Sekolah Menengah Pertama Dalam Pembelajaran Daring Di Masa Pandemi Covid-19. Refleksi Edukatika: Jurnal Ilmiah Kependidikan, 11(1), 102-108.

Sahidillah, M.W \& Miftahurrisqi, P. 2019. Whatsapp sebagai Media Literasi Digital Siswa. Jurnal Varia Pendidikan, Vol. 31, No. 1, Juni 2019: 52-57

Sawitri, D. 2020. Penggunaan Google Meet Untuk Work From Home Di Era Pandemi Coronavirus Disease 2019 (Covid-19). 2020. Jurnal Pengabdian Masyarakat, 2(1)

Setyorini, I. (2020). Pandemi COVID-19 Dan Online Learning: Apakah Berpengaruh Terhadap Proses Pembelajaran Pada Kurikulum 13?. Journal of Industrial Engineering \& Management Research, 1(1), 95-102.

Sriyatun, S. 2021. Analisis Pembelajaran Daring Berbantuan Aplikasi Whatsapp, Google Meet, dan Schoology. Jurnal ALLAMA, 2(4)

Suryadi, E., Ginanjar, M. H., \& Priyatna, M. (2018). Penggunaan Sosial Media WhatsApp dan Pengaruhnya terhadap Disiplin Belajar Peserta Didik pada Mata Pelajaran Pendidikan Agama Islam. Jurnal Edukasi Islami Jurnal Pendidikan Islam, 07(1), 1-22. 